\title{
A Review of Therapeutic Antibodies in Breast Cancer
}

\author{
Maryam Eini ${ }^{1}$, Nahid Zainodini ${ }^{1}$, Hamed Montazeri ${ }^{2}$, Parastoo Mirzabeigi ${ }^{3}$, Parastoo Tarighi $^{1}$ \\ ${ }^{1}$ Department of Medical Biotechnology, Faculty of Allied Medicine, Iran University of Medical Sciences, Tehran, Iran; \\ ${ }^{2}$ School of Pharmacy-International Campus, Iran University of Medical Sciences, Tehran, Iran; ${ }^{3}$ Clinical Pharmacy \\ Department, School of Pharmacy, Iran University of Medical Sciences, Tehran, Iran
}

Corresponding authors: Parastoo Tarighi, Department of Medical Biotechnology, Faculty of Allied Medicine, Iran University of Medical Sciences, Tehran, Iran; TEL: +989122713060; email: tarighi.p@iums.ac.ir; Parastoo Mirzabeigi, Clinical Pharmacy Department, School of Pharmacy, Iran University of Medical Sciences, Tehran, Iran; TEL:+989123420796 email: pmirzabeygi@gmail.com

Received, May 11, 2021; Revised, July 13, 2021; Accepted. July 14, 2021; Published, July 21, 2021

\begin{abstract}
Since the first production of monoclonal antibodies about 35 years ago, researchers have found them useful in the treatment and diagnosis of various diseases such as cancer. By developing different types of monoclonal antibodies such as humanized, drug conjugated, or bispecific ones, researchers, have achieved remarkable success in treating several complicated and challenging diseases, targeting specific antigens or receptors makes monoclonal antibodies the right choice to inhibit signaling pathways like programmed deathligand 1 (PD-L1) or programmed death1 (PD-1) and changing cell behavior. As one of the most common types of malignancies among women, breast cancer is one of the most critical conditions which different types of monoclonal antibodies were designed and produced to treat. Therefore, we reviewed these antibodies in breast cancer, their targets, and their efficacy and toxicity, with more focus on recent PD-L1or PD-1 inhibitor antibodies in breast cancer and beyond.
\end{abstract}

\section{INTRODUCTION}

According to the American Cancer Society, breast cancer is among the four most frequent cancers; the four being those of lung, colorectal, breast, and prostate (1). It is estimated that 276,480 new cases will be diagnosed with breast cancer in 2020 in the United States of America (2). The global incidence of breast cancer is approximately 2.3 million cases in 2020, and breast cancer as the most frequent malignancy among women surpassed lung cancer (3). According to the International Agency for Research on Cancer (IARC), the rate of women's death due to breast cancer was 684,996 cases worldwide in 2020. As a leading cause of female cancer death, breast cancer accounted for about $15.5 \%$ of total cancer-related deaths in women (3). Although these figures indicate the severity of breast cancer risk among women, its lethal rate has decreased by $1.8 \%$ per year from 2007 to 2016 due to the improvements in early detection and treatment stages. Accordingly, the main treatment patterns are surgery, radiation therapy, chemotherapy, hormone therapy, and targeted therapy (4). Targeted therapy is one of the approaches which usually help treatments by increasing the specificity of cancer therapy, improving the patient's survival, and decreasing the tumor relapse $(5,6)$. By targeting a particular marker, monoclonal antibodies are considered one of the most practical and promising approaches (7). For example, based on the reports in early-stage HER2+ breast cancer, the patients are treated with trastuzumab plus chemotherapy, the risk of disease recurrence and death decreased about $52 \%$ and $33 \%$, respectively, compared to the patients with administration of chemotherapy alone (8).

In general, monoclonal antibodies are biomolecules which are capable of targeting a particular antigen. The first product of this class approved by the United States Food and Drug Administration (FDA) in the late 1980s, was OKT3, a murine anti-CD3 monoclonal antibody which was indicated for the treatment of organ transplant rejection (9). Along with developing biotechnological techniques, the structure of monoclonal antibodies was evolved from murine, chimeric, and humanized antibodies to fully human antibodies through recombinant DNA, transgenic, and phage display technologies (10). In this manner, the issues such as the incomplete binding of human $\mathrm{Fc}$ receptors and $\mathrm{Fc}$ region of murine immunoglobulins, development of human anti- 
mouse antibodies, and clearance of murine antibodies could be resolved $(11,12)$. Different monoclonal antibodies' mechanisms have been proposed depending on the molecular characteristics such as cytotoxicity, modification of immune signaling, cellular activation/ interactivity, limitation of growing and proliferation, and foreign entities deactivation (13).

Over the last two decades, monoclonal antibodies have become an interesting therapeutic option to treat different types of breast cancer because of their specific targeting ability and overall response rate $(14,15)$. Breast cancer has different histological or molecular subtypes. Gene expression profiling studies are the main determinants of molecular subtypes. The groups of genes which the molecular classification of breast cancer is done based on their overexpression are estrogen receptor (ER), progesterone receptor (PR), and members of epidermal growth factor receptor (EGFR) family of receptor tyrosine kinases, including HER2 (Human epidermal growth factor receptor 2) and EGFR $(16,17)$. ER and PR are two hormone receptors (HR) that drive breast cancer progression (18). ER is expressed in $75 \%$ of breast cancers overall and acts as a ligand-responsive transcription factor. Subsequent binding ER to its ligand, ERs dimerize and get into the nucleus, where they bind to estrogen response elements (EREs) and stimulate transcription of genes related to cell proliferation and growth (18). Other proteins over-expressed in breast cancer are epidermal growth factor receptors such as HER2 and EGFR. All members have a similar structure containing four extracellular domains, a transmembrane region, and an intracellular tyrosine kinase domain (19). Binding EGFR and HER2 receptors to growth factors cause hetero or homodimerization of receptors which activate the autophosphorylation of intracellular tyrosine kinase domain of the receptor. Phosphorylated tyrosine kinase domain drives different signaling pathways such as PI3K/AKT/TOR, RAS/MAPK, JAK/STAT, and phospholipase $\mathrm{C} \gamma$ (PLC $\gamma$ ), which lead to tumorigenesis and cellular proliferation $(20,21)$. Based on overexpression or lack of mentioned receptor proteins, breast cancer is categorized into some molecular subtypes, including HR+ (defined by overexpression of hormone receptors like estrogen or/and progesterone receptor), EGFR, and HER2+ (defined by overexpression of the family of epidermal growth factor receptor), and triplenegative breast cancer (defined by a lack of the expression of estrogen, progesterone, and the HER2 receptors) (16). Targeted breast cancer therapy can be performed by interfering with one of the molecules of cancerous cells due to the type of breast cancer such as HER2. However, there is a recent approach inhibiting the immune checkpoint by different antibodies (22). Conjugation of antibodies with drugs is the other treatment approach (23). In this article, different types of monoclonal antibodies, from the most common monoclonal antibodies to treat breast cancer to more recently developed ones, as illustrated in Figure 1, will be overviewed .

\section{COMMON THERAPEUTIC ANTIBODIES AGAINST BREAST CANCER}

Harboring overexpression of human epidermal growth factor receptor 2 (HER2) is observed in about $15-20 \%$ of breast cancer patients, making HER2 a potential target in developing therapeutic approaches. In this way, many monoclonal antibodies were produced that target HER2. Trastuzumab (Herceptin), as the first HER2 targeting approved humanized monoclonal antibody (IgG1), is considered for HER2 positive patients as first-line neoadjuvant therapy, in which a therapeutic agent is administered before the main treatment such as surgery (24). Trastuzumab is prescribed for earlystage and metastatic cases $(8,25)$. A recent study showed that the combination therapy of trastuzumab with capecitabine (a chemotherapy medication) and tucatinib (a small molecule inhibiting HER2) could result in better overall survival in heavily pretreated patients who are suffering from HER2+ metastatic breast cancer (15).

Another FDA-approved neoadjuvant antibody is pertuzumab which targets the dimerization domain of HER2 (extracellular domain 2) and blocks signaling pathways (26). In two APHINITY and CLEOPATRA trials, a combination of pertuzumab with trastuzumab plus chemotherapy or docetaxel improved invasive disease-free survival (DFS) and prolonged median overall survival (OS) by 15.7 months, respectively $(27,28)$. Understanding interaction between tumors and immune system has resulted to design and develop a new type of HER2targeting antibodies. Margetuximab as a recent antiHER2 chimeric IgG monoclonal antibody with engineered $\mathrm{Fc}$ binds to CD16A by more high affinity. CD16A is an Fc-receptor on immune cells, which plays a role in antibody-dependent cell-mediated cytotoxicity. In $78 \%$ of response-evaluable patients receiving margetuximab, tumor reduction was 
observed; however, treatment has constitutional symptoms such as pyrexia, nausea, anemia, diarrhea, and fatigue. Margetuximab is currently in phase II clinical trial (29). Bispecific antibodies are another biotechnological advance in designing antibodies with special attention in oncotherapy (30). Recent drugs targeting HER2 are MCLA 128 and ZW25 which are novel bispecific antibodies. MCLA 128 targets HER2 and HER3 receptors. This antibody is under clinical trial examination on metastatic breast cancer as well as on some other tumors. This antibody can limit tumor progression by inhibiting HER2/HER3 dimers and their downstream HRG/HER3 pathway and phosphatidylinositide-3 kinase (PI3K)/Akt signaling (31). ZW25 targets two domains of HER 2 simultaneously. These domains are extracellular domains 4 , binding domains of trastuzumab, and extracellular domains 2 , binding domains of pertuzumab (32). Basic HER2-directed antibodies have been summarized in Figure 2.

In addition to HER2, other therapeutic targets are used to develop monoclonal antibodies, including vascular endothelial growth factor (VEGF), prolactin receptor, and Robo1 receptor (

Table 1). Bevacizumab is a monoclonal antibody that interferes with vascular endothelial growth factor (VEGF) and inhibits it from binding to its receptor on vascular endothelium. This approach was performed on HER2-negative patients. However, this antibody failed to show significant improvement in overall survival results $(33,34)$. LFA102 is another humanized antibody targeting the extracellular domain of prolactin receptor. LFA102 significantly inhibited the receptor signaling pathway in estrogen receptor-positive rat mammary cancer model. This antibody is now in Phase 1 clinical trial to treat advanced or metastatic breast cancer (35). In a recent study in 2019, it was reported that an $\operatorname{IgG} 2 b$ monoclonal antibody named R5 was effective to inhibiti breast cancer by targeting the Robo1 receptor, which plays a role in angiogenesis. In a xenograft tumor model mice study, R5 could suppress breast cancer progression by inhibiting angiogenesis and downregulation of filamin A (FLNA). It showed that R5 could be a promising therapy for patients (36).

Toxicity: Cardiotoxicity and heart failure are the most considerable issues for the side effect of administering of trastuzumab and pertuzumab (37). Treatment with margetuximab has constitutional symptoms such as pyrexia, nausea, anemia, diarrhea, and fatigue (29). ZW25 is quite tolerable and does not have severe adverse events (32). Bevacizumab has evidence of intestinal perforation which is induced by the antibody $(33,34)$.

\section{ANTIBODY-DRUG CONJUGATES AGAINST BREAST CANCER}

By shedding more light on the underlying mechanism of breast cancer action, the number of molecules which could be targeted has expanded (Table 1). There are various monoclonal antibodydrug conjugates that target different molecules such as HER2 (targeted more than others), glycoprotein non-metastatic, trophoblast cell surface antigen, CA6 (a sialoglycotope of MUC1), LIV-1 (a multi-pass transmembrane protein), protein tyrosine kinase 7 (PTK7), lysosomal membrane-associated proteins LAMP-1, P-cadherin (a cell surface glycoprotein), ephrin A4 (a family member of RTKs). One of the approved antibody-drug conjugates to target HER2 is ado-trastuzumab emtansine (Kadcyla, TDM-1) $(38,39)$, which is made of trastuzumab (targeting HER2) and a microtubule inhibitor drug (DM1). After the internalization of antibodies into the cells expressing antigen, the drug is released and causes cell death by inhibiting microtubule assembly. TDM1 is the drug to treat metastatic breast cancer patients who have primarily been prescribed trastuzumab and taxane (40). TDM-1 showed higher progression-free survival and overall survival in HER2-positive advanced breast cancer patients than combination therapy of lapatinib-capecitabin $(30.8 \%$ and 6.4 months versus $43.6 \%$ and 9.6 months). Lapatinib is an orally active small-molecule inhibitor of HER2 tyrosine kinases, and capecitabin is an epidermal growth factor receptor type 1 (EGFR) inhibitor and a chemotherapy medication (38). MEDI-4276, XMT1522, and ARX788 are other antibody-drug conjugates that target HER2 and deliver microtubule inhibitors as well (41-44). Moreover, DS-8201a, SYD985, and ADCT-502 anti-HER2 antibodies that respectively deliver deruxtecan (topoisomerase I inhibitor), duocarmazine (a potent DNA alkylating agent), and pyrrolobenzodiazepine (DNA crosslinker) (45-51). Trastuzumab deruxtecan (trastuzumab with topoisomerase I inhibitor conjugate) is the second drug conjugated antibody after a phase 2 clinical trial (DESTINY-Breast01, NCT03248492) has recently been approved by FDA. Results indicate that trastuzumab deruxtecan was quite effective on the patients with metastatic, unresectable, and/or HER2-positive breast cancer who have had anti-HER2 treatment previously (52). LCB14-0110 and MI30004 are two other HER2- 


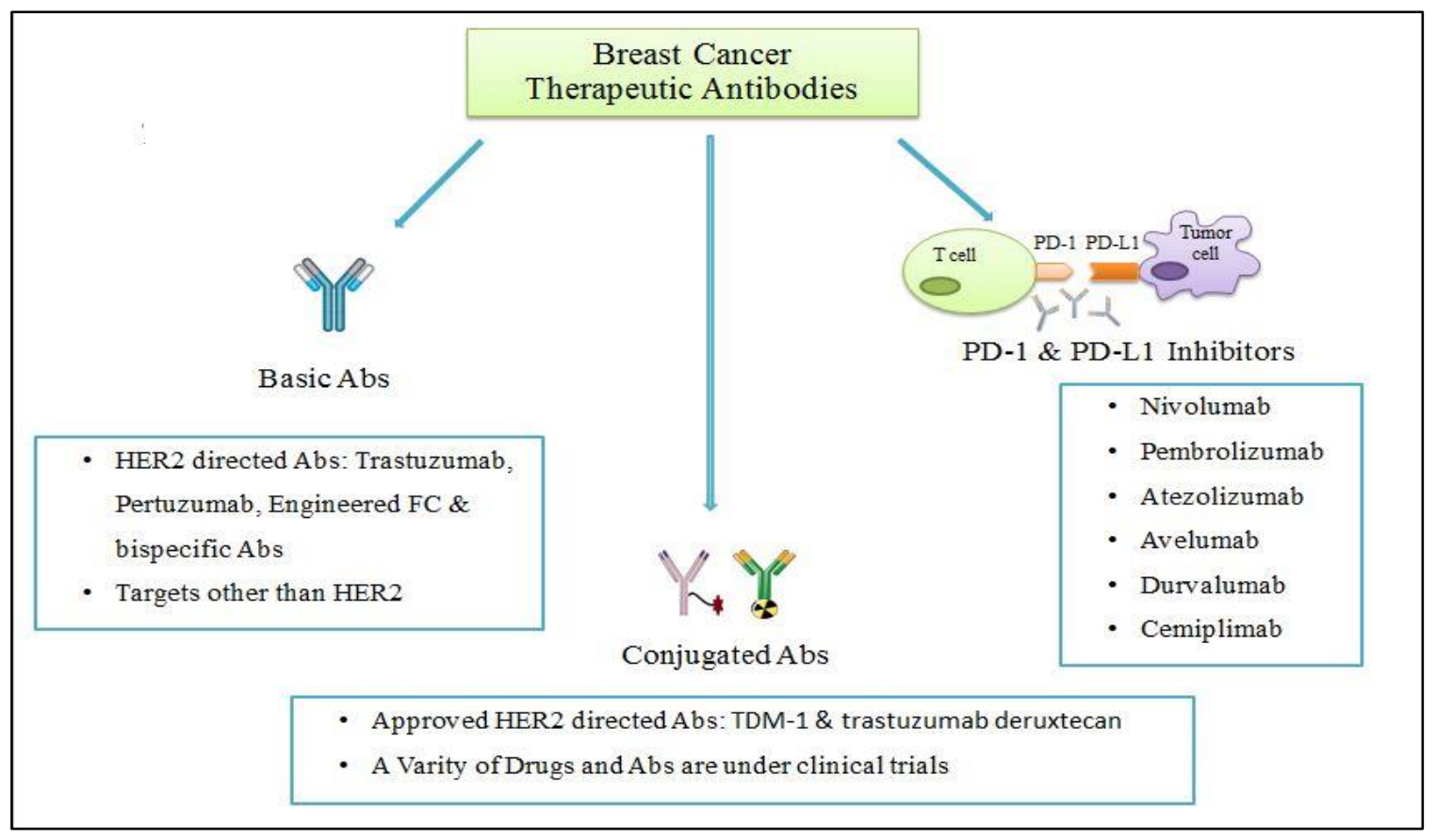

Figure 1. Different types of monoclonal antibodies are used to treat breast cancer.

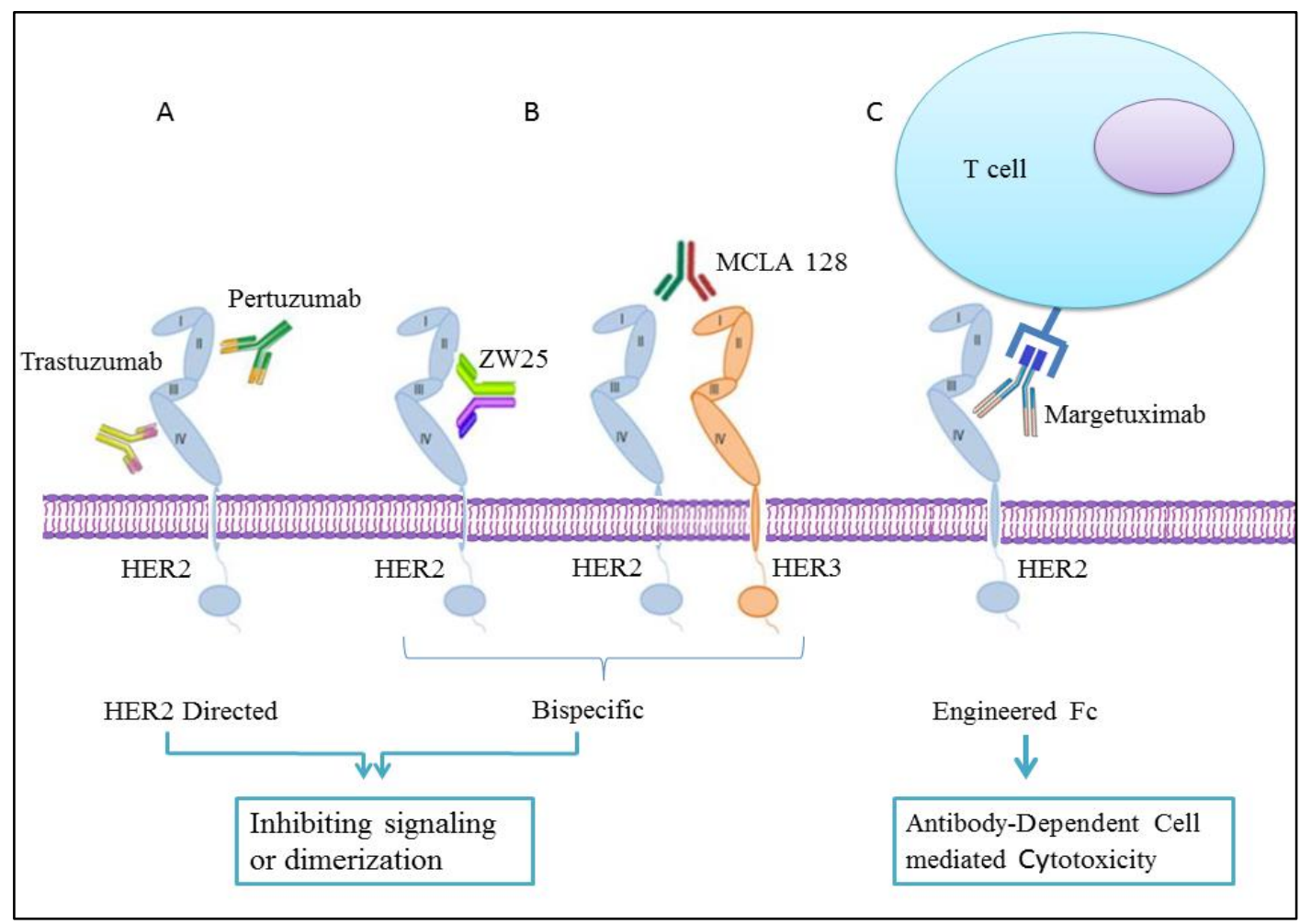

Figure 2. Different approaches in targeting HER2. A: Humanized monoclonal antibody targeting just one kind of receptor; B: Bispecific antibody inhibiting two different targets; C: Antibody with engineered Fc receptor that induces better antibodydependent cell-mediated toxicity. 
directed drug conjugated antibodies in preclinical trials which are composed of trastuzumab linked to monomethyl auristatin F (MMAF) and PM050489, respectively. No data were published for LCB140110, while MI30004 has a significant tumor growth inhibitory effect in gastric, breast, and ovarian cancer cell lines compared to trastuzumab therapy $(53,54)$. Amoozadeh et al.also reported that trastuzumab conjugated to diphtheria toxin or truncated pseudomonas exotoxin A could reduce the effective dose of trastuzumab and increase its efficiency in HER2 positive cell breast cancer cell lines (55).

As mentioned, there are other proteins which drug conjugated antibodies have targeted, and some of these antigens, their antibodies, and conjugated drugs are summarized as follows. Glycoprotein nonmetastatic antigen is targeted by glembatumumab vedotin (CDX-011), which is a monoclonal antibody (Mab) linked to a microtubule inhibitor (monomethyl auristatin E (MMAE)) (56). The objective response rate (ORR) of triple-negative breast cancer (TNBC) patients treated by CDX-011 antibody was $18 \%$ (57). Trophoblast cell surface antigen is targeted by sacituzumab govitecan (IMMU-132) monoclonal antibody which is conjugated to $\mathrm{SN}-38$ (topoisomerase I inhibitor) (58). ORR of 69 heavily pre-treated advanced patients with metastatic TNBC who received IMMU-132 was $30 \%$ (59). Another protein is CA6, a sialoglycotope of MUC1, a tumorassociated antigen targeted by SAR566658 Mab that delivers S-methyl-DM4 (60). The other is LIV-1, a multi-pass transmembrane protein targeted by IgG1 humanized mLIV22 Mab carrying the auristatin analog MMAE as a drug (61). Protein Tyrosine Kinase 7 (PTK7) is an aim for humanized IgG1 h6M24 Mab. This Mab is conjugated to another auristatin analog named Aur0101(62) and showed partial remissions (PR) in two of three TNBC patients in an initial clinical study (63). LAMP-1, a lysosomal membrane-associated protein, is the other drug conjugated antibody target. LAMP- 1 is targeted by SAR428926 Mab which is conjugated to DM4 (64). P-cadherin is a cell surface glycoprotein, and which is targeted by PCA062 Mab. This Mab is loaded with maytansinoid (DM1) (65). Ephrin A4, a family member of RTKs, is the target for PF$06647263 \mathrm{Mab}$. This antibody is conjugated to calicheamicin, and its partial response is about $10 \%$ (66).

Toxicity: A meta-analysis was done for the first FDA-approved drug conjugated antibody (TDM1) adverse events, which reported musculoskeletal pain, fatigue, nausea, epistaxis, increased transaminases, headache, bleeding, constipation, and thrombocytopenia as the most common effects (67).

\section{PD-1 INHIBITORS AND PD-L1 INHIBITORS AS MORE RECENT APPROACH FOR CANCER TREATMENT}

PD-1 (CD279) as a member of CD28 family has an inhibitory effect. It plays an essential role in tumor immune escape. PD-1 expression occurs on many cells, including activated monocytes, activated $\mathrm{T}$ cells, natural killer (NK) T cells, B cells, and dendritic cells (68). The interactivity of PD-1 and its ligand PD-L1 (CD274 or B7-H1) can suppress the proliferation and survival of $\mathrm{T}$ lymphocytes and stimulate programmed cell death in $\mathrm{T}$ cells-related tumors. Moreover, this interaction promotes CD4+ T cells differentiated into forkhead box P3 (Foxp3+) regulatory $\mathrm{T}$ cells and makes tumor cells more resistant against cytotoxic $\mathrm{T}$ lymphocytes (CTL) attack. Accordingly, if PD-1 signaling is blocked, it can stimulate anti-tumor responses (69).

PD-L1 availability in tumor affects PD-1 associated immune resistance. PD-L1 expression can be checked and controlled using PI3K-Akt kinases increasing or IFN- $\gamma$ 's secretion and the variability in two general types of innate and adaptive immune resistance caused by PD-L1 expression (70). Research showed that although PD-1 expression significantly regulated B cells' differentiation, no relevant correlation was observed in PD-1 levels remaining in pro-B cells (an early stage of mature $B$ cell) irrelevantly, and differentiation of $B$ cells increases the number of PD-1 (71).

Moreover, agonistic compounds of toll-like receptor 9 (TLR9) activating by PD-1 can significantly enhance B-cells' maturation. As a result, when B cells confront PD-1 activity blockage, antigen-specific antibody responses improve. This revealed PD-1's character to inhibit B cell-mediated T-cell activation (72). Treatments related to PD-1 and its ligand's Antibodies have shown noticeable feedback in different tumors. In the following, antibodies associated with PD-1/ PD-L1 and their receptors in breast cancer and other malignancies are described (Table1).

\section{Nivolumab}

Nivolumab (Opdivo®), as an anti-PD-1 monoclonal antibody with great affinity, was shown to help treat unresectable malignant melanoma in Japan (73). Nivolumab is a fully human IgG4 monoclonal antibody against PD-1, which is intravenously 
Table 1. Monoclonal antibodies (MAbs) are used for the treatment of breast cancer.

\begin{tabular}{|c|c|c|c|c|c|c|c|}
\hline $\begin{array}{l}\text { Type of Ab } \\
(\text { a n t i b od y ) }\end{array}$ & Ab name & $\begin{array}{l}\text { Construction or } \\
\text { modification of } \mathrm{Ab}\end{array}$ & Ab target & Ab effect or efficacy & Ab side effect & $\begin{array}{l}\text { Clinical trial } \\
\text { phase }\end{array}$ & Reference \\
\hline \multirow{8}{*}{ Basic Abs } & $\begin{array}{l}\text { Trastuzumab } \\
\text { (Herceptin) }\end{array}$ & Humanized & $\begin{array}{l}\text { extracellular domains } 4 \text { of HER } \\
2 \text { receptor }\end{array}$ & $\begin{array}{l}\text { in combination with } \\
\text { chemotherapy } \\
\text { improves overall } \\
\text { survival efficacy }\end{array}$ & $\begin{array}{l}\text { Cardiotoxicity and } \\
\text { heart failure }\end{array}$ & Phase IV & (24) \\
\hline & Pertuzumab & Humanized & $\begin{array}{l}\text { extracellular domains } 2 \text { of HER } \\
2 \text { receptor }\end{array}$ & $\begin{array}{l}\text { Inhibits receptor } \\
\text { dimerization and } \\
\text { downstream signaling }\end{array}$ & $\begin{array}{l}\text { Cardiotoxicity and } \\
\text { heart failure }\end{array}$ & Phase IV & (26) \\
\hline & Bevacizumab & Humanized & $\begin{array}{l}\text { vascular endothelial growth } \\
\text { factor (VEGF) }\end{array}$ & $\begin{array}{l}\text { Did not show a } \\
\text { prolonged overall } \\
\text { survival }\end{array}$ & $\begin{array}{l}\text { Atherosclerotic } \\
\text { blood vessels, } \\
\text { coronary artery } \\
\text { disease, intestinal } \\
\text { perforation }\end{array}$ & Phase IV & $(33,34)$ \\
\hline & LFA102 & Humanized & prolactin receptor & $\begin{array}{l}\text { inhibits the receptor } \\
\text { signaling pathway }\end{array}$ & Currently studying & Phase I & (35) \\
\hline & R5 & Humanized & Robo1 receptor & inhibiting angiogenesis & Currently studying & Phase II & (36) \\
\hline & Margetuximab & Engineered $\mathrm{Fc}$ & $\begin{array}{l}\text { Fab: HER2 engineered Fc: bind } \\
\text { by more elevated affinity to } \\
\text { CD16A (an Fc-receptor which } \\
\text { play a role in antibody- } \\
\text { dependent cell-mediated } \\
\text { cytotoxicity) }\end{array}$ & $\begin{array}{l}\text { reduction of the tumor } \\
\text { in } 78 \% \text { of response- } \\
\text { evaluable patients }\end{array}$ & $\begin{array}{l}\text { pyrexia, nausea, } \\
\text { anemia, diarrhea, } \\
\text { and fatigue }\end{array}$ & Phase II & (29) \\
\hline & MCLA 128 & Bispecific Ab & both HER2 and HER3 & $\begin{array}{l}\text { Inhibits downstream } \\
\text { PI3K/Akt signaling }\end{array}$ & Currently studying & Phase II & (31) \\
\hline & ZW25 & Bispecific Ab & $\begin{array}{l}\text { extracellular domains } 4 \text { and } 2 \text { of } \\
\text { HER } 2 \text { receptor }\end{array}$ & ORR: $44 \%$ & well tolerated & Phase II & (32) \\
\hline \multirow[b]{2}{*}{$\begin{array}{l}\text { Drug } \\
\text { conjugated Abs }\end{array}$} & $\begin{array}{l}\text { TDM-1, MEDI- } \\
\text { 4276, XMT-1522 } \\
\text { and ARX788 }\end{array}$ & $\begin{array}{l}\text { microtubule inhibitors such } \\
\text { as DM1 }\end{array}$ & \multirow{2}{*}{ HER2 } & \multirow{2}{*}{$\begin{array}{l}\text { TDM-1 showed an } \\
\text { overall survival of } 9.6 \\
\text { months }\end{array}$} & \multirow{2}{*}{$\begin{array}{l}\text { fatigue, nausea, } \\
\text { vomiting, mucosal } \\
\text { inflammation, } \\
\text { thrombocytopenia, } \\
\text { and diarrhea }\end{array}$} & \multirow{2}{*}{$\begin{array}{l}\text { T-DM1: Phase } \\
\text { III } \\
\text { MEDI-4276: } \\
\text { Phase I } \\
\text { XMT-1522: } \\
\text { Phase I } \\
\text { ARX788: Phase } \\
\text { I } \\
\text { DS-8201a: } \\
\text { Phase } 3 \\
\text { SYD985: Phase } \\
\text { III } \\
\text { ADCT-502: } \\
\text { Phase I }\end{array}$} & \multirow[t]{2}{*}{$(40)$} \\
\hline & $\begin{array}{l}\text { DS-8201a, } \\
\text { SYD985, } \\
\text { ADCT-502 }\end{array}$ & $\begin{array}{l}\text { topoisomerase inhibitor, } \\
\text { DNA alkylating agent, } \\
\text { Crosslinkers to DNA }\end{array}$ & & & & & \\
\hline
\end{tabular}

Table 1. continues... 


\begin{tabular}{|c|c|c|c|c|c|c|}
\hline $\begin{array}{l}\text { Glembatumumab } \\
\text { vedotin }(\mathrm{CDX}-011)\end{array}$ & $\begin{array}{l}\text { microtubule inhibitor named } \\
\text { monomethyl auristatin E } \\
\text { (MMAE) }\end{array}$ & glycoprotein non-metastatic & ORR: $18 \%$ TNBC & $\begin{array}{l}\text { fatigue, rash, nausea, } \\
\text { peripheral } \\
\text { neuropathy, and } \\
\text { neutropenia with } \\
\text { treatment related } \\
\text { rash potentially }\end{array}$ & Phase I/ II & $(56,57)$ \\
\hline $\begin{array}{l}\text { Sacituzumab } \\
\text { govitecan }\end{array}$ & $\begin{array}{l}\text { SN-38 a topoisomerase I } \\
\text { inhibitor }\end{array}$ & trophoblast cell surface antigen & ORR: $30 \%$ & Well-tolerated & Phase I & $(58,59)$ \\
\hline SAR566658 & S-methyl-DM4 & CA6 a sialoglycotope of MUC1 & $\begin{array}{l}3 \text { PR in breast cancer } \\
\text { patients }\end{array}$ & $\begin{array}{l}\text { Fatigue, peripheral } \\
\text { neuropathy, nausea, } \\
\text { abdominal pain, and } \\
\text { diarrhea. }\end{array}$ & Phase II & $(60)$ \\
\hline $\begin{array}{l}\text { mLIV22 } \\
\text { (SGN-LIV1A) }\end{array}$ & auristatin analog MMAE & $\begin{array}{l}\text { LIV-1 a multi-pass } \\
\text { transmembrane protein }\end{array}$ & Currently studying & Currently studying & Phase II & $(61)$ \\
\hline h6M24 & auristatin analog Aur0101 & $\begin{array}{l}\text { Protein Tyrosine Kinase } 7 \\
\text { (PTK7) }\end{array}$ & $P R$ in $2 / 3$ of patients & tolerated & Phase I & $(63)$ \\
\hline SAR428926 & DM4 & $\begin{array}{l}\text { lysosomal membrane-associated } \\
\text { proteins LAMP-1 }\end{array}$ & $\begin{array}{l}\text { regressions of } \\
\text { established breast }\end{array}$ & Currently studying & Phase I & (64) \\
\hline $\begin{array}{l}\text { PCA062 } \\
\text { (an IgG1 Mab) }\end{array}$ & maytansinoid DM1 & $\begin{array}{l}\text { P-cadherin a cell surface } \\
\text { glycoprotein }\end{array}$ & $\begin{array}{l}\text { Antigen-specific } \\
\text { cytotoxicity. }\end{array}$ & Currently studying & Phase I & $(65)$ \\
\hline
\end{tabular}

Table 1. continues... 


\begin{tabular}{|c|c|c|c|c|c|c|c|}
\hline & PF-06647263 & Calicheamicin & $\begin{array}{l}\text { ephrin A4, a family member of } \\
\text { RTKs }\end{array}$ & PR: $36.7 \%$ & $\begin{array}{l}\text { fatigue, nausea, } \\
\text { vomiting, mucosal } \\
\text { inflammation, } \\
\text { thrombocytopenia, } \\
\text { and diarrhea }\end{array}$ & Phase I & (66) \\
\hline \multirow{6}{*}{$\begin{array}{l}\text { PD-1 and PD- } \\
\text { L1 inhibitors }\end{array}$} & Nivolumab & Humanized & PD-1 & ORR $22 \%$ & No reports & Phase II & (75) \\
\hline & Pembrolizumab & Humanized & PD-1 & $\begin{array}{l}\text { ORR } 18.5 \% \\
\text { OS: } 8.9 \text { months } \\
\text { PFS: } 2 \text { months }\end{array}$ & $\begin{array}{l}\text { Fatigue, Nausea } \\
\text { Hypothyroidism } \\
\text { hyperthyroidism } \\
\text { Pneumonitis, } \\
\text { Diarrhea }\end{array}$ & Phase I & (80) \\
\hline & Atezolizumab & Humanized & PD-L1 & $\begin{array}{l}\text { ORR: } 24 \% \\
\text { PFS: } 1.4 \text { months }\end{array}$ & $\begin{array}{l}\text { Pyrexia, Fatigue, } \\
\text { Nausea Diarrhea, } \\
\text { Asthenia, Pruritus }\end{array}$ & Phase I & $(85)$ \\
\hline & Avelumab & Humanized & $\begin{array}{l}\text { PD-1 and PD-L1 interaction } \\
\text { inhibitory, } \\
\text { ADCC induction }\end{array}$ & $\begin{array}{l}\text { ORR: } 5.2 \% \\
\text { PFS: } 5.9\end{array}$ & $\begin{array}{l}\text { Pyrexia, Fatigue, } \\
\text { Nausea Diarrhea, } \\
\text { Asthenia, Pruritus, } \\
\text { Hypothyroidism } \\
\text { Autoimmune } \\
\text { hepatitis } \\
\text { Pneumonitis, } \\
\text { Thrombocytopenia, } \\
\text { Dry eye, } \\
\text { Hyperthyroidism, } \\
\text { Pemphigoid }\end{array}$ & Phase Ib & (91) \\
\hline & Durvalumab & Humanized & $\begin{array}{l}\text { PD-L1 attachment to PD-1 and } \\
\text { CD80 }\end{array}$ & $\begin{array}{l}\text { ORR: } 17 \% \text { total, } \\
0 \% \text { ER-positive } \\
43 \% \text { TNBC, } \\
\text { PFS: not reached in } \\
\text { TNBC } \\
2.2 \text { months ER- } \\
\text { positive }\end{array}$ & $\begin{array}{l}\text { Hepatitis, water- } \\
\text { electrolyte } \\
\text { imbalance, Rash }\end{array}$ & Phase I & (95) \\
\hline & Cemiplimab & Humanized & PD-1 & $\begin{array}{l}13 \% \text { of complete } \\
\text { response and } 31 \% \text { of } \\
\text { partial response }\end{array}$ & $\begin{array}{l}\text { One treatment- } \\
\text { related death after } \\
\text { the onset of } \\
\text { aspiration } \\
\text { pneumonia }\end{array}$ & $\begin{array}{l}\text { Squamous Cell } \\
\text { Carcinoma: } \\
\text { Phase II } \\
\text { Lung cancer: } \\
\text { Phase III } \\
\text { Myeloma: } \\
\text { Phase 1/Phase 2 }\end{array}$ & $(97-99)$ \\
\hline
\end{tabular}


administered. It was found to contain linear pharmacokinetics related to partial tumor response in almost one-fourth of Japanese patients who were previously treated for advanced melanoma (74). TONIC trial was used as an ongoing phase II trial for five groups of patients with metastatic triple-negative breast cancer (mTNBC) who received sedative chemotherapy, doxorubicin, cyclophosphamide, cisplatin, and no treatment. Following completing the induction treatment, nivolumab $3 \mathrm{mg} / \mathrm{kg}$ was considered for all patients, and obtained result was an objective response rate of (ORR) 22\%, complete remissions of (CRs) 4\%, and nine partial remissions (PRs) of $18 \%$. A favorable response rate was observed after receiving nivolumab following the other treatments such as chemotherapy or irradiation, compared to single blocking PD-1/PD-L1 studies in TNBC (75).

In a project, patients suffering from advanced melanoma were entered from 2008 to 2012 and treated by intravenous nivolumab in an outpatient clinic every two weeks for a whole period of 96 weeks. Patients were monitored for overall survival, long-term safety, and response duration after stopping the treatment. After the nivolumab treatment in patients suffering from advanced treatment-refractory melanoma, the researcher favorably compared overall survival rate with studies on patients with similar symptoms. The obtained responses were persistent, and long-term safety was acceptable after drug discontinuation (76).

Toxicity: The adverse effect of nivolumab associated with immune system profile and its association with clinical activity in Non-small-cell lung carcinoma (NSCLC) was investigated via a multi-institutional retrospective study using landmark and multivariable analyses. The multivariable analysis results suggested that side effects positively associated with survival outcome, progression-free survival (PFS), and overall survival rate (OS). Developing adverse events was related to the survival outcome of nivolumab treatment in patients suffering from advanced or recurrent NSCLC (77).

\section{Pembrolizumab}

Pembrolizumab (Keytruda $\left.{ }^{\circledR}\right)$ is a monoclonal $\mathrm{IgG} 4$ kappa antibody with humanized and PD-1 blocking characteristics. It was first approved in the USA in 2014 for metastatic melanoma (unresectable) in the patients whose disease progressed after being treated with ipilimumab and also for patients who carried a mutation in BRAF gene to inhibit BRAF.
Pembrolizumab is the first anti-PD-1 treatment that received regulatory approval in the US $(78,79)$. Recently, a two-part experiment (KEYNOTE-086) was conducted on women suffering from mTNBC. First, pembrolizumab was analyzed in terms of potency and assurance in mTNBC patients who were previously treated by at least one systemic therapy for metastatic disease. Besides, mTNBC patients with PD-L1 who received no treatment were administered with a standard dose of pembrolizumab. The value of disease control was $7.6 \%$, and the mean PFS and OS were maintained for two months and 8.9 months, respectively. PD-L1 had a significant effect on PFS and OS (80).

Toxicity: In the mentioned study, $60 \%$ of patients experienced adverse outcomes related to the treatment. Nevertheless, not more than $12.4 \%$ of patients faced toxic reactions (grade 3 or 4 ). The most frequent adverse outcomes were fatigue $(20.6 \%)$ and nausea (10.6\%). Besides, $18.8 \%$ of patients complained about immunological side effects such as pneumonitis and thyroid Disease (hypothyroidism and hyperthyroidism). The most frequent side effects of Cohort B of KEYNOTE-086 were diarrhea (13\%), nausea (15\%), and exhaustion $(31 \%)(80)$.

\section{Atezolizumab}

Atezolizumab (TecentriqTM), a human-modified monoclonal immunoglobulin G1 antibody, contains a selectively binding feature to PD-L1 and pursued by blockage of its collaboration with PD-1 and B7-1 (81). Genentech first developed atezolizumab as a subsidiary of Hoffmann-La Roche with binding affinity dissociation constant $(\mathrm{Kd})=0.4 \mathrm{nM}$, which can have inhibitory effects on PD-1 and its ligand interactivity, without any impact on the cooperation of PD-1 with PD-L2 (called B7-DC or CD273). PDL2 interaction with PD-1 contributes to maintaining peripheral tolerance in the lung (82).

In phase 1 of trial, the long-lasting reactions of atezolizumab were studied in cases with metastatic bladder cancer. Responses were immense in individuals with a greater degree of PD-L1 expression on immune cells infiltrating the tumor than lower degrees. Single-agent atezolizumab is approved to treat metastatic urothelial carcinoma and NSCLC (83). The results of a study by Schmid et al. suggested that PFS could be improved following the parallel use of atezolizumab and nab-paclitaxel in the patients suffering from mTNBC (84). Emens et al. designed a phase 1 study to explore the atezolizumab activity against tumors in mTNBC patients. 
Atezolizumab also displayed sturdy clinical activity and measurable ORR. A greater number of ORR was found in patients with mTNBC treated in the firstline setting. The patients with objective response or stable disease (SD) had a higher chance of survival at data cut off for at least 24 weeks. Some patients showed abnormal reactions to atezolizumab. The nonparametric and multifactor analyses indicated that $\mathrm{CD} 8+\mathrm{T}$ cells and immune complexes with PDL1 directly affect clinical activity (85).

Toxicity: Atezolizumab is tolerable in the patients with mTNBC. The frequent adverse effects were pyrexia, fatigue, nausea, diarrhea, asthenia, and pruritus. The most serious side effects developed during the first year of administration, and solely a patient faced lichen planus during treatment (85).

\section{Avelumab}

Avelumab (BavencioTM) as a PD-L1-blocking human antibody was firstly approved in the USA to treat adults and children suffering from Merkel cell carcinoma (MCC) (86). Avelumab artificially utilizes the mechanism of antibody-dependent cellmediated cytotoxicity (ADCC); hence, this makes it specific among PD-1 antibodies, suppressing checkpoints. Therefore, avelumab can deplete positive tumor and stromal cells for PD-L1 via ADCC. Besides, avelumab can activate T-cells and the adaptive immune system by suppressing the PD$\mathrm{L} 1$ connections. Avelumab can also retain a native $\mathrm{Fc}$ region and engage the innate immune responses (87, 88).

Julia et al. developed an experimental project on collecting cells related to TNBC to explore ADCC mediated by avelumab. Their results indicated that avelumab significantly provoked ADCC in PD-L1 expressing tumor cells, compared to control group (peripheral blood mononuclear cell (PBMC) or NK cells) (89). The international clinical development project for avelumab (JAVELIN) has implemented about 30 clinical projects for approximately 4000 individuals on 15 types of tumors (90). JAVELIN trial examined avelumab in a group of metastatic breast cancer (MBC) people disregarding the expression of PD-L1. The ORR of the whole population was low at $4.8 \%$ with $25 \%$ SD, while ORR in the patients with triple-negative disease was higher $(5.2 \%)$ with $25.9 \%$ SD. In PD-L1- positive TNBC, ORR was $44.4 \%$. Notably, study responses and no median length of reaction were seen during this procedure. $27.9 \%$ of whole $\mathrm{MBC}$ patients and $45.7 \%$ of TNBC patients showed a reduction in their tumor sizes (91). A clinical trial of avelumab and palbociclib in metastatic triple-negative breast cancer (PAveMenT) is being recruited.

Toxicity: Acute and lethal deleterious reactions related to the immune system are identified as negative outcomes of avelumab treatment. Each biological system can be affected by these complications, and recurrence can happen after prescription. The immunologic reaction was found among 1738 patients treated with avelumab in JAVELIN solid tumor and JAVELIN Merkel 200, including pneumonitis, hepatitis, colitis, diabetes mellitus (type 1), nephritis, thyroid disorders, and adrenal insufficiency. Moreover, one-fourth of cases displayed side effects related to infusion (439 of 1738 patients) (92).

\section{Durvalumab}

Durvalumab (ImfinziTM) is a monoclonal antibody against human immunoglobulin G1 specific kappa chain, which selectively inhibits PD-L1 attachment to PD-1 and CD80 without any impact PD-L2 binding. The effects of durvalumab were explored for head and neck squamous cell carcinoma (HNSCC), hematologic cancers, NSCLC, pancreatic cancer, gastric cancer, mesothelioma, hepatocellular carcinoma, and breast cancer (93). In 2017, durvalumab was approved by US FDA to treat patients who have urothelial cancer (metastatic or advanced type) who had no improvement, even meanwhile or subsequent therapies either by platinum or by neoadjuvant or adjuvant plus platinum (94). ORR and duration of response helped approve, and further support for this indication depends on the confirmation and statement of clinical benefits in confirming studies (94).

Santa-Maria et al. designed a single-arm pilot study to assess tremelimumab and durvalumab impacts on ORR and immunological features in people suffering from TNBC or metastatic endocrine receptor (ER) positive. The result was $17 \%, 0 \%, 43 \%$ ORR in the whole study group, ER-positive subjects, and TNBC, respectively. Noticeably, no PFS and OS goals were reached in TNBC; however, ER-positive cases showed 2.2 months PFS without any OS (95). In another clinical study, the combination therapy of durvalumab and trastuzumab was performed on fifteen heavily pretreated HER2-positive metastatic breast cancer patients; however, no significant result was observed. PD-L1 expression was less than 1\% on archive tissues of patients, which could be a possible explanation of not responding to treatment (96). 
Toxicity: Hepatitis, water-electrolyte imbalance, and rash (without any grade 4 or 5 side effects) were the most common related adverse events of durvalumab in TNBC or metastatic endocrine receptor (ER) positive patients (95).

\section{Cemiplimab}

Cemiplimab (Libtayo) is the most recent antibody in this category which was approved in 2018. It is an anti-PD-1 monoclonal antibody used for metastatic cutaneous squamous cell carcinoma, lung cancer, and myeloma (97-99). Administering cemiplimab in a study on 78 patients with locally advanced cutaneous squamous cell carcinoma and no accepted standard of care showed $13 \%$ of complete response, $31 \%$ of partial response, and one treatment-related death (97). For the patients with NSCLC and tumors expressing PD-L1 $>50 \%$, a comparative study between pembrolizumab monotherapy vs. combinations of cemiplimab, ipilimumab, and platinum-based doublet chemotherapy is performing in Phase 3 (98). Cemiplimab combined with isatuximab is in phase 1/phase 2 to treat relapsed/refractory multiple myeloma patients (99). For hormone receptor-positive HER2 negative or triple-negative breast cancer, the first clinical trial was launched.

\section{CONCLUSION}

The design and development of different antibodies have undergone significant progress. The modern antibodies are considered one of the most promising tools to treat breast cancer in the future. Today, HER2 is one of the most important therapeutic targets in breast cancer, and administration of herceptin is one of the routine parts of treatment patterns which have improved patient outcomes. The clinical application of HER2 directed antibodies is extended even beyond breast cancer. It is being investigated in other solid tumors, including gastric, colorectal, biliary tract, bladder, and non-small-cell lung cancers (100). However, projects such as detecting new targets, standardization of older antibodies, and developing and testing novel ones in clinical experiments can be programmed and performed.

Drug conjugates are the other important type of monoclonal antibodies. Their assessment in a variety of diseases indicates the potential as promising anticancer drugs. Drug conjugated antibody emerging data would help choose the appropriate targets, optimizing antibodies, and their conjugation to drugs and load of drugs (40). However, there is still some resistance to therapy in some cases and HER2+ metastatic breast cancer due to different reasons. For instance, altered intracellular signaling or escape from ADCC is among the causes of resistance against trastuzumab or dual HER2 blockade. Therefore, understanding the underlying mechanism of action or resistance of therapies would be necessary to decrease the treatment failure rate (101). Recently some advanced technical approaches, including microfluidics, were used in the antibody-drug research. These techniques can provide 3D models and implement high-throughput screening, which seems to be quite applicable for antibody-drug conjugates investigation due to their high number in the research stage (102). Moreover, more varieties of combinations of antibody and chemotherapies and small molecules could be investigated (103).

Immune checkpoint inhibitor antibodies are the other recent developments in monoclonal antibodies treating cancer and showed improved control of metastatic advanced stage tumor or triple-negative cancer, which have more limited therapeutic options (104). Combination therapy of immune checkpoint inhibitor antibodies along with other treatments is another emerging era of study. Mouse models research demonstrated that the combination therapy of anti- PD-1 antibody and drug conjugated antibody (trastuzumab deruxtecan) is more effective than monotherapy of each drug (105).

The last but not the least point is the price of monoclonal antibody therapies estimated to be $\$ 100,000$ per person annually (106). Although the treatment is expensive, the cost is lower than other targeted therapies such as those for CAR-T cell that costs about $\$ 373,000$ and $\$ 475,000$ per treatment (107).

ACKNOWLEDGMENT. This study was performed by affiliation of Department of Medical Biotechnology, Faculty of Allied Medicine, Iran University of Medical Sciences, Tehran, Iran.

COMPLIANCE WITH ETHICAL STANDARDS. This article does not contain any studies with human participants or animals performed by any of the authors.

CONFLICT OF INTEREST. The authors declare that they have no conflict of interest. 


\section{REFERENCES}

1. Siegel RL, Miller KD, Jemal A. Cancer statistics, 2019. CA: a cancer journal for clinicians. 2019;69(1):7-34. doi: 10.3322/ caac. 21551.

2. Society AC. American cancer society: Cancer facts and figures. Atlanta: American Cancer Society. 2020.

3. Sung H, Ferlay J, Siegel RL, Laversanne M, Soerjomataram I, Jemal A, et al. Global cancer statistics 2020: GLOBOCAN estimates of incidence and mortality worldwide for 36 cancers in 185 countries. CA: a cancer journal for clinicians. 2021;71(3):209-49. doi: 10.3322/caac. 21660

4. Society AC. Breast cancer facts \& figures 2017-2018. American Cancer Society Atlanta, GA; 2017.

5. Keyvani V, Farshchian M, Esmaeili S-A, Yari H, Moghbeli M, Nezhad S-RK, et al. Ovarian cancer stem cells and targeted therapy. Journal of Ovarian Research. 2019;12(1):120. doi: 10.1186/s13048-019-0588-z.

6. Liu D. Cancer biomarkers for targeted therapy. BioMed Central; 2019. doi: 10.1186/s40364-019-0178-7.

7. Kong D-H, Kim MR, Jang JH, Na H-J, Lee S. A review of anti-angiogenic targets for monoclonal antibody cancer therapy. International journal of molecular sciences. 2017;18(8):1786. doi: 10.3390/ijms18081786.

8. Romond EH, Perez EA, Bryant J, Suman VJ, Geyer Jr CE, Davidson NE, et al. Trastuzumab plus adjuvant chemotherapy for operable HER2-positive breast cancer. New England journal of medicine. 2005;353(16):1673-84. doi: 10.1056/NEJMoa052122.

9. Kung P, Goldstein G, Reinherz EL, Schlossman SF. Monoclonal antibodies defining distinctive human $\mathrm{T}$ cell surface antigens. Science. 1979;206(4416):347-9. doi: 10.1126/science. 314668 .

10. Ribatti D. From the discovery of monoclonal antibodies to their therapeutic application: An historical reappraisal. Immunology letters. 2014;161(1):96-9. doi: 10.1016/j.imlet. 2014.05.010.

11. Bruhns P. Properties of mouse and human IgG receptors and their contribution to disease models. Blood. 2012;119(24):5640-9. doi: 10.1182/blood-2012-01-380121.
12. Clark M. Antibody humanization: a case of the 'Emperor's new clothes'? Immunology today. 2000;21(8):397-402. doi: 10.1016/s01675699(00)01680-7.

13. Rodgers KR, Chou RC. Therapeutic monoclonal antibodies and derivatives: Historical perspectives and future directions. Biotechnology advances. 2016;34(6):114958. doi: 10.1016/j.biotechadv.2016.07.004.

14. Wong WM. Trastuzumab: Anti-HER2 Antibody for Treatment of Metastatic Breast Cancer. Cancer practice. 1999;7(1):48-50. doi: 10.1046/j.1523-5394.1999.07108.x.

15. Murthy RK, Loi S, Okines A, Paplomata E, Hamilton E, Hurvitz SA, et al. Tucatinib, Trastuzumab, and Capecitabine for HER2Positive Metastatic Breast Cancer. New England Journal of Medicine. 2019. doi: 10.1056/NEJMoa1914609.

16. Masoud V, Pagès G. Targeted therapies in breast cancer: New challenges to fight against resistance. World journal of clinical oncology. 2017;8(2):120. doi: 10.5306/wjco.v8.i2.120.

17. do Nascimento RG, Otoni KM. Histological and molecular classification of breast cancer: what do we know? Mastology. 2020;30:1-8. doi: 10.29289/25945394202020200024.

18. Maqbool SN, Lim SC, Park KC, Hanif R, Richardson DR, Jansson PJ, et al. Overcoming tamoxifen resistance in oestrogen receptorpositive breast cancer using the novel thiosemicarbazone anti-cancer agent, DpC. British journal of pharmacology. 2020;177(10):2365-80. doi: 10.1111/bph.14985.

19. Arienti C, Pignatta S, Tesei A. Epidermal growth factor receptor family and its role in gastric cancer. Frontiers in oncology. 2019;9:1308. doi: 10.3389/fonc.2019.01308.

20. Loibl S, Gianni L. HER2-positive breast cancer. The Lancet. 2017;389(10087):241529. doi: 10.1016/S0140-6736(16)32417-5.

21. Hsu JL, Hung M-C. The role of HER2, EGFR, and other receptor tyrosine kinases in breast cancer. Cancer and Metastasis Reviews. 2016;35(4):575-88. doi: 10.1007/s10555-0169649-6.

22. Emens LA. Breast cancer immunotherapy: facts and hopes. Clinical Cancer Research. 2018;24(3):511-20. doi: 10.1158/10780432.CCR-16-3001.

23. Altunay B, Morgenroth A, Beheshti M, Vogg A, Wong NC, Ting HH, et al. HER2-directed 
antibodies, affibodies and nanobodies as drugdelivery vehicles in breast cancer with a specific focus on radioimmunotherapy and radioimmunoimaging. European Journal of Nuclear Medicine and Molecular Imaging. 2020:1-19. doi: 10.1007/s00259-020-050941.

24. Mastro LD, Lambertini M, Bighin C, Levaggi A, D'Alonzo A, Giraudi S, et al. Trastuzumab as first-line therapy in HER2-positive metastatic breast cancer patients. Expert review of anticancer therapy. 2012;12(11):1391-405. doi: 10.1586/ era.12.107.

25. Slamon DJ, Leyland-Jones B, Shak S, Fuchs $\mathrm{H}$, Paton V, Bajamonde A, et al. Use of chemotherapy plus a monoclonal antibody against HER2 for metastatic breast cancer that overexpresses HER2. New England journal of medicine. 2001;344(11):783-92. doi: 10.1056/ NEJM200103153441101.

26. Nami B, Maadi H, Wang Z. Mechanisms underlying the action and synergism of trastuzumab and pertuzumab in targeting HER2-positive breast cancer. Cancers. 2018;10(10):342. doi: 10.3390/cancers10100342.

27. Baselga J, Cortés J, Kim S-B, Im S-A, Hegg $\mathrm{R}, \mathrm{Im} \mathrm{Y}-\mathrm{H}$, et al. Pertuzumab plus trastuzumab plus docetaxel for metastatic breast cancer. New England Journal of Medicine. 2012;366(2):109-19. doi: 10.1056/ NEJMoa1113216.

28. Von Minckwitz G, Procter M, de Azambuja E, Zardavas D, Benyunes $\mathrm{M}$, Viale $\mathrm{G}$, et al. Adjuvant pertuzumab and trastuzumab in early HER2-positive breast cancer. New England Journal of Medicine. 2017;377(2):122-31. doi: 10.1056/NEJMoa1703643.

29. Bang YJ, Giaccone G, Im S-A, Oh D-Y, Bauer $\mathrm{T}$, Nordstrom J, et al. First-in-human phase 1 study of margetuximab (MGAH22), an Fcmodified chimeric monoclonal antibody, in patients with HER2-positive advanced solid tumors. Annals of Oncology. 2017;28(4):85561. doi: 10.1093/annonc/mdx002.

30. Suurs FV, Lub-de Hooge MN, de Vries EG, de Groot DJA. A review of bispecific antibodies and antibody constructs in oncology and clinical challenges. Pharmacology \& therapeutics. 2019;201:103-19. doi: 10.1016/j.pharmthera.2019.04.006.
31. Geuijen CA, De Nardis C, Maussang D, Rovers E, Gallenne T, Hendriks LJ, et al. Unbiased combinatorial screening identifies a bispecific IGG1 that potently inhibits HER3 signaling via HER2-guided ligand blockade. Cancer cell. 2018;33(5):922-36. e10. doi: 10.1016/j.ccell.2018.04.003.

32. Bartsch R, Bergen E. ASCO 2018: highlights in HER2-positive metastatic breast cancer. memo-Magazine of European Medical Oncology. 2018;11(4):280-3. doi: 10.1007/s12254-018-0441-X.

33. Fujii Y, Hirahara N, Kaji S, Taniura $T$, Hyakudomi R, Yamamoto $\mathrm{T}$, et al. Bevacizumab-induced intestinal perforation in a patient with inoperable breast cancer: a case report and review of the literature. Journal of medical case reports. 2018;12(1):84. doi: 10.1186/s13256-018-1619-x.

34. Varella L, Abraham J, Kruse M, editors. Revisiting the role of bevacizumab in the treatment of breast cancer. Seminars in oncology; 2017: Elsevier. doi: 10.1053/j.seminoncol.2017.10.010.

35. Damiano JS, Rendahl KG, Karim C, Embry MG, Ghoddusi M, Holash J, et al. Neutralization of prolactin receptor function by monoclonal antibody LFA102, a novel potential therapeutic for the treatment of breast cancer. Molecular cancer therapeutics. 2013;12(3):295-305. doi: 10.1158/15357163.MCT-12-0886.

36. Li Q, Cao J, He Y, Liu X, Mao G, Wei B, et al. R5, a neutralizing antibody to Robo1, suppresses breast cancer growth and metastasis by inhibiting angiogenesis via down-regulating filamin A. Experimental Cell Research. 2019:111756. doi: 10.1016/j.yexcr. 2019.111756.

37. Gavilá J, Oliveira M, Pascual T, Perez-Garcia J, Gonzàlez X, Canes J, et al. Safety, activity, and molecular heterogeneity following neoadjuvant non-pegylated liposomal doxorubicin, paclitaxel, trastuzumab, and pertuzumab in HER2-positive breast cancer (Opti-HER HEART): an open-label, singlegroup, multicenter, phase 2 trial. BMC medicine. 2019;17(1):8. doi: 10.1186/s12916018-1233-1.

38. Verma S, Miles D, Gianni L, Krop IE, Welslau $\mathrm{M}$, Baselga J, et al. Trastuzumab emtansine for HER2-positive advanced breast cancer. New England Journal of Medicine. 
2012;367(19):1783-91.

doi:

10.1056/NEJMoa1209124.

39. Amiri-Kordestani L, Blumenthal GM, Xu QC, Zhang L, Tang SW, Ha L, et al. FDA approval: ado-trastuzumab emtansine for the treatment of patients with HER2-positive metastatic breast cancer. Clinical Cancer Research. 2014;20(17):4436-41. doi: 10.1158/10780432.

40. Trail PA, Dubowchik GM, Lowinger TB. Antibody drug conjugates for treatment of breast cancer: novel targets and diverse approaches in ADC design. Pharmacology \& therapeutics. 2018;181:126-42. doi: 10.1016/j.pharmthera.2017.07.013.

41. Li JY, Perry SR, Muniz-Medina V, Wang X, Wetzel LK, Rebelatto MC, et al. A biparatopic HER2-targeting antibody-drug conjugate induces tumor regression in primary models refractory to or ineligible for HER2-targeted therapy. Cancer cell. 2016;29(1):117-29. doi: 10.1016/j.ccell.2019.05.010.

42. Thompson P, Fleming R, Bezabeh B, Huang $\mathrm{F}$, Mao S, Chen $\mathrm{C}$, et al. Rational design, biophysical and biological characterization of site-specific antibody-tubulysin conjugates with improved stability, efficacy and pharmacokinetics. Journal of controlled release. 2016;236:100-16. doi: 10.1016/j. jconrel.2016.06.025.

43. Yurkovetskiy A, Gumerov D, Ter-Ovanesyan E, Conlon P, Devit M, Bu C, et al. Non-clinical pharmacokinetics of XMT-1522, a HER2 targeting auristatin-based antibody drug conjugate. AACR; 2017. doi: 10.1158/15387445.

44. Humphreys R, Kirtely J, Hewit A, Biroc S, Knudsen N, Skidmore L, et al. Abstract 639: Site specific conjugation of ARX-788, an antibody drug conjugate (ADC) targeting HER2, generates a potent and stable targeted therapeutic for multiple cancers. Cancer Res. 2015;75:639. doi: 10.1158/1538-7445.

45. Ogitani Y, Abe Y, Iguchi T, Yamaguchi J, Terauchi T, Kitamura $M$, et al. Wide application of a novel topoisomerase I inhibitor-based drug conjugation technology. Bioorganic \& medicinal chemistry letters. 2016;26(20):5069-72. doi: 10.1016/j.bmcl.2016.08.082.

46. Ogitani Y, Aida T, Hagihara K, Yamaguchi J, Ishii C, Harada N, et al. DS-8201a, a novel HER2-targeting ADC with a novel DNA topoisomerase I inhibitor, demonstrates a promising antitumor efficacy with differentiation from T-DM1. Clinical Cancer Research. 2016;22(20):5097-108. doi: 10.1158/1078-0432.

47. Ogitani $\mathrm{Y}$, Hagihara $\mathrm{K}$, Oitate $\mathrm{M}$, Naito $\mathrm{H}$, Agatsuma T. Bystander killing effect of DS8201a, a novel anti-human epidermal growth factor receptor 2 antibody-drug conjugate, in tumors with human epidermal growth factor receptor 2 heterogeneity. Cancer science. 2016;107(7):1039-46. doi: 10.1111/cas.12966.

48. Elgersma RC, Coumans RG, Huijbregts T, Menge WM, Joosten JA, Spijker HJ, et al. Design, synthesis, and evaluation of linkerduocarmycin payloads: toward selection of HER2-targeting antibody-drug conjugate SYD985. Molecular pharmaceutics. 2015;12(6):1813-35. doi: 10.1021/mp500781a.

49. Banerji U, van Herpen CM, Saura C, Thistlethwaite F, Lord S, Moreno V, et al. Trastuzumab duocarmazine in locally advanced and metastatic solid tumours and HER2-expressing breast cancer: a phase 1 dose-escalation and dose-expansion study. The Lancet Oncology. 2019;20(8):1124-35. doi: 10.1016/S1470-2045(19)30328-6.

50. Zammarchi F, Chivers S, Williams DG, Adams L, Mellinas-Gomez M, Tyrer P, et al. ADCT-502, a novel pyrrolobenzodiazepine (PBD)-based antibody-drug conjugate (ADC) targeting low HER2-expressing solid cancers. Eur J Cancer. 2016;69:S28. doi: 10.1016/S0959-8049(16)32662-4.

51. Modi S, Saura C, Yamashita T, Park YH, Kim S-B, Tamura K, et al. Trastuzumab Deruxtecan in Previously Treated HER2Positive Breast Cancer. New England Journal of Medicine. 2019.2 doi: 10.1056/NEJMoa1914510.

52. Modi S, Saura C, Yamashita T, Park YH, Kim S-B, Tamura K, et al. Trastuzumab deruxtecan in previously treated HER2-positive breast cancer. New England Journal of Medicine. 2020;382(7):610-21.

doi: 10.1056/NEJMoa1914510.

53. Park M-H, Byeon J-J, Shin S-H, Choi J, Park Y, Park Y-H, et al. Quantification of an Antibody-Conjugated Drug in Fat Plasma by an Affinity Capture LC-MS/MS Method for a Novel Prenyl Transferase-Mediated Site- 
Specific Antibody-Drug Conjugate. Molecules. 2020;25(7):1515. doi: 10.3390/molecules25071515.

54. Avilés P, Dominguez JM, Guillén MJ, MuñozAlonso MJ, Mateo C, Rodriguez-Acebes R, et al. MI130004, a novel antibody-drug conjugate combining trastuzumab with a molecule of marine origin, shows outstanding In Vivo activity against HER2-expressing tumors. Molecular cancer therapeutics. 2018;17(4):786-94. doi: 10.1158/1535-7163.

55. Amoozadeh S, Hemmati M, Farajollahi MM, Akbari N, Tarighi P. Preparation of Diphtheria and Pseudomonas Exotoxin A Immunotoxins and Evaluation of Their Cytotoxicity Effect on SK-BR-3, BT-474, and MDA-MB-231 Breast Cancer Cell Lines. Cancer investigation. 2019;37(10):546-57.

doi: 10.1080/07357907.2019.1655761.

56. Doronina SO, Toki BE, Torgov MY, Mendelsohn BA, Cerveny CG, Chace DF, et al. Development of potent monoclonal antibody auristatin conjugates for cancer therapy. Nature biotechnology. 2003;21(7):778. doi: 10.1038/nbt832.

57. Yardley DA, Weaver R, Melisko ME, Saleh MN, Arena FP, Forero A, et al. EMERGE: A randomized phase II study of the antibodydrug conjugate glembatumumab vedotin in advanced glycoprotein NMB-expressing breast cancer. Journal of Clinical Oncology. 2015;33(14):1609-19.

doi: 10.1200/JCO.2014.56.2959.

58. Cardillo TM, Govindan SV, Sharkey RM, Trisal P, Goldenberg DM. Humanized antiTrop-2 IgG-SN-38 conjugate for effective treatment of diverse epithelial cancers: preclinical studies in human cancer xenograft models and monkeys. Clinical Cancer Research. 2011;17(10):3157-69. doi: 10.1158/1078-0432.

59. Bardia A, Mayer IA, Diamond JR, Moroose RL, Isakoff SJ, Starodub AN, et al. Efficacy and safety of anti-trop-2 antibody drug conjugate sacituzumab govitecan (IMMU132) in heavily pretreated patients with metastatic triple-negative breast cancer. Journal of Clinical Oncology. 2017;35(19):2141. doi: 10.1200/JCO. 2016.70 .8297$.

60. Widdison WC, Wilhelm SD, Cavanagh EE, Whiteman KR, Leece BA, Kovtun Y, et al. Semisynthetic maytansine analogues for the targeted treatment of cancer. Journal of medicinal chemistry. 2006;49(14):4392-408. doi: 10.1021/jm060319f.

61. Sussman D, Smith LM, Anderson ME, Duniho S, Hunter JH, Kostner H, et al. SGN-LIV1A: A Novel Antibody-Drug Conjugate Targeting LIV-1 for the Treatment of Metastatic Breast Cancer. Molecular cancer therapeutics. 2014;13(12):2991-3000. doi: 10.1158/15357163.

62. Maderna A, Doroski M, Subramanyam C, Porte A, Leverett CA, Vetelino BC, et al. Discovery of cytotoxic dolastatin 10 analogues with $\mathrm{N}$-terminal modifications. Journal of medicinal chemistry. 2014;57(24):10527-43. doi: 10.1021/jm501649k.

63. Tolcher A, Calvo E, Maitland M, Gibson B, Xuan D, Joh T, et al. 28LBA A phase 1 study of PF-06647020, an antibody-drug conjugate targeting PTK7, in patients with advanced solid tumors. European Journal of Cancer. 2015;51:S724. doi: 10.1093/annonc/mdw435.29.

64. Baudat Y, Cameron B, Dabdoubi T, Lefebvre A-M, Merino-Trigo A, Thomas C, et al. Characterization of a novel maytansinoidantibody-drug conjugate targeting LAMP1 expressed at the surface of tumor cells. AACR; 2016. doi: 10.1158/1538-7445.

65. Menezes D, Abrams TJ, Karim C, Tang Y, Ying C, Miller $\mathrm{K}$, et al. Development and activity of a novel antibody-drug conjugate for the treatment of P-cadherin expressing cancers. AACR; 2015. doi: 10.1158/15387445.

66. Garrido-Laguna I, Krop I, Burris III HA, Hamilton E, Braiteh F, Weise AM, et al. Firstin-human, phase I study of PF-06647263, an anti-EFNA4 calicheamicin antibody-drug conjugate, in patients with advanced solid tumors. International journal of cancer. 2019. doi: 10.1002/ijc.32154.

67. Poon KA, Flagella K, Beyer J, Tibbitts J, Kaur S, Saad O, et al. Preclinical safety profile of trastuzumab emtansine (T-DM1): mechanism of action of its cytotoxic component retained with improved tolerability. Toxicology and applied pharmacology. 2013;273(2):298-313. doi: 10.1016/j.taap.2013.09.003.

68. Nguyen LT, Ohashi PS. Clinical blockade of PD1 and LAG3 - potential mechanisms of 
action. Nature Reviews Immunology. 2015;15(1):45. doi: 10.1038/nri3790.

69. Zitvogel L, Kroemer G. Targeting PD-1/PDL1 interactions for cancer immunotherapy. Taylor \& Francis; 2012. doi: 10.1056/NEJMoa1200694.

70. Pardoll DM. The blockade of immune checkpoints in cancer immunotherapy. Nature Reviews Cancer. 2012;12(4):252. doi: 10.1038/nrc3239.

71. Thibult M-L, Mamessier E, Gertner-Dardenne J, Pastor S, Just-Landi S, Xerri L, et al. PD-1 is a novel regulator of human $\mathrm{B}$-cell activation. International immunology. 2012;25(2):12937. doi: 10.1093/intimm/dxs098.

72. Ohaegbulam KC, Assal A, Lazar-Molnar E, Yao Y, Zang X. Human cancer immunotherapy with antibodies to the PD-1 and PD-L1 pathway. Trends in molecular medicine. 2015;21(1):24-33. doi: 10.1016/j.molmed.2014.10.009.

73. Deeks ED. Nivolumab: a review of its use in patients with malignant melanoma. Drugs. 2014;74(11):1233-9. doi: 10.1007/s40265014-0234-4.

74. Coyne GS, Madan RA, Gulley JL, Sutherland J, Goldberg G, Hammett M. Nivolumab: promising survival signal coupled with limited toxicity raises expectations. J Clin Oncol. 2014;32(10):986-8.

doi: 10.1200/JCO.2013.54.5996.

75. Kok M, Horlings $H$, Van de Vijver K, Wiersma T, Russell N, Voorwerk L, et al. LBA14Adaptive phase II randomized noncomparative trial of nivolumab after induction treatment in triple negative breast cancer: TONIC-trial. Annals of Oncology. 2017;28(suppl_5). doi: 10.1093/annonc/mdx440.006.

76. Topalian SL, Sznol M, McDermott DF, Kluger HM, Carvajal RD, Sharfman WH, et al. Survival, durable tumor remission, and long-term safety in patients with advanced melanoma receiving nivolumab. Journal of clinical oncology. 2014;32(10):1020. doi: 10.1200/JCO.2013.53.0105.

77. Haratani K, Hayashi H, Chiba Y, Kudo K, Yonesaka K, Kato R, et al. Association of immune-related adverse events with nivolumab efficacy in non-small-cell lung cancer. JAMA oncology. 2018;4(3):374-8. doi: 10.1001/jamaoncol.2017.2925.
78. Katz H, Alsharedi M. Immunotherapy in triple-negative breast cancer. Medical Oncology. 2018;35(1):13. doi: 10.1007/s12032-017-1071-6.

79. Nanda R, Chow LQ, Dees EC, Berger R, Gupta S, Geva R, et al. Pembrolizumab in patients with advanced triple-negative breast cancer: phase Ib KEYNOTE-012 study. Journal of Clinical Oncology. 2016;34(21):2460-7. doi: 10.1200/JCO.2015.64.8931.

80. Adams S, Schmid P, Rugo HS, Winer EP, Loirat D, Awada A, et al. Phase 2 study of pembrolizumab (pembro) monotherapy for previously treated metastatic triple-negative breast cancer (mTNBC): KEYNOTE-086 cohort A. American Society of Clinical Oncology; $2017 . \quad$ doi: 10.1093/annonc/mdy517.

81. Rosenberg JE, Hoffman-Censits J, Powles T, Van Der Heijden MS, Balar AV, Necchi A, et al. Atezolizumab in patients with locally advanced and metastatic urothelial carcinoma who have progressed following treatment with platinum-based chemotherapy: a single-arm, multicentre, phase 2 trial. The Lancet. 2016;387(10031):1909-20. doi: 10.1016/S0140-6736(16)00561-4.

82. Markham A. Atezolizumab: first global approval. Drugs. 2016;76(12):1227-32. doi: 10.1007/s40265-016-0618-8.

83. Petrylak DP, Powles T, Bellmunt J, Braiteh FS, Loriot Y, Cruz Zambrano C, et al. A phase Ia study of MPDL3280A (anti-PDL1): Updated response and survival data in urothelial bladder cancer (UBC). American Society of Clinical Oncology; 2015. doi: 10.1200/jco.2015.33.15_suppl.4501.

84. Schmid P, Adams S, Rugo HS, Schneeweiss $\mathrm{A}$, Barrios $\mathrm{CH}$, Iwata $\mathrm{H}$, et al. Atezolizumab and nab-paclitaxel in advanced triple-negative breast cancer. New England Journal of Medicine. 2018;379(22):2108-21. doi: 10.1056/NEJMoa1809615.

85. Emens LA, Cruz C, Eder JP, Braiteh F, Chung C, Tolaney SM, et al. Long-term clinical outcomes and biomarker analyses of atezolizumab therapy for patients with metastatic triple-negative breast cancer: a phase 1 study. JAMA oncology. 2019;5(1):7482. doi: 10.1001/jamaoncol.2018.4224. 
86. Kim ES. Avelumab: First global approval. Drugs. 2017;77(8):929-37. doi: 10.1007/s40265-017-0749-6.

87. Grenga I, Donahue RN, Lepone LM, Richards J, Schlom J. A fully human IgG1 anti-PD-L1 $\mathrm{MAb}$ in an in vitro assay enhances antigenspecific T-cell responses. Clinical \& translational immunology. 2016;5(5):e83. doi: 10.1038/cti.2016.27.

88. Emens LA, Ascierto PA, Darcy PK, Demaria $\mathrm{S}$, Eggermont AM, Redmond WL, et al. Cancer immunotherapy: opportunities and challenges in the rapidly evolving clinical landscape. European Journal of Cancer. 2017;81:116-29.

doi:

10.1016/j.ejca.2017.01.035.

89. Juliá EP, Amante A, Pampena MB, Mordoh J, Levy EM. Avelumab, an IgG1 anti-PD-L1 immune checkpoint inhibitor, triggers NK cell-mediated cytotoxicity and cytokine production against Triple Negative Breast Cancer cells. Frontiers in immunology. 2018;9:2140. doi: 10.3389/fimmu. 2018.02140.

90. Beatty S, O’Neill L. FDA Grants Approval for BAVENCIO®(avelumab), the First Immunotherapy Approved for Metastatic Merkel Cell Carcinoma. 2017.

91. Dirix LY, Takacs I, Jerusalem G, Nikolinakos $\mathrm{P}$, Arkenau H-T, Forero-Torres A, et al. Avelumab, an anti-PD-L1 antibody, in patients with locally advanced or metastatic breast cancer: a phase 1b JAVELIN Solid Tumor study. Breast cancer research and treatment. 2018;167(3):671-86. doi: 10.1007/s10549-017-4537-5.

92. Inc. ES, Inc P. Bavencio®(avelumab) injection: US prescribing information. 2017.

93. Stewart R, Morrow M, Hammond SA, Mulgrew K, Marcus D, Poon E, et al. Identification and Characterization of MEDI4736, an Antagonistic Anti-PD-L1 Monoclonal Antibody. Cancer immunology research. 2015;3(9):1052-62. doi: 10.1158/2326-6066.

94. Food U, Administration D. Imfinzi (durvalumab) prescribing information. FDA; 2018.

95. Santa-Maria CA, Kato T, Park J-H, Kiyotani K, Rademaker A, Shah AN, et al. A pilot study of durvalumab and tremelimumab and immunogenomic dynamics in metastatic breast cancer. Oncotarget. 2018;9(27):18985. doi: 10.18632/oncotarget.24867.

96. Chia SK, Bedard PL, Hilton J, Amir E, Gelmon KA, Goodwin RA, et al. A phase I study of a PD-L1 antibody (Durvalumab) in combination with trastuzumab in HER-2 positive metastatic breast cancer (MBC) progressing on prior anti HER-2 therapies (CCTG IND. 229)[NCT02649686]. American Society of Clinical Oncology; 2018. doi: 10.1634/theoncologist.2019-0321.

97. Migden MR, Khushalani NI, Chang ALS, Lewis KD, Schmults CD, Hernandez-Aya L, et al. Cemiplimab in locally advanced cutaneous squamous cell carcinoma: results from an open-label, phase 2, single-arm trial. The Lancet Oncology. 2020. doi: 10.1016/S1470-2045(19)30728-4.

98. Rizvi N, Lee S, Curtis P, Caldwell W, Gao B, Rietschel P. EMPOWER-Lung 3: A Phase 3 Study of Cemiplimab, Ipilimumab and Chemotherapy in Advanced NSCLC with PDL1< 50\%: P3. 04-25. Journal of Thoracic Oncology. 2018;13(10). doi: 10.1016/j.jtho. 2018.08.1732.

99. Hradska K, Kascak M, Hajek R, Jelinek T. Identifying and treating candidates for checkpoint inhibitor therapies in multiple myeloma and lymphoma. Expert Review of Hematology. 2020;13(4):375-92. doi: 10.1080/17474086.2020.1733405.

100. Oh D-Y, Bang Y-J. HER2-targeted therapies - a role beyond breast cancer. Nature Reviews Clinical Oncology. 2020;17(1):33-48. doi: 10.1038/s41571-0190268-3.

101. Vernieri C, Milano M, Brambilla M, Mennitto A, Maggi C, Cona MS, et al. Resistance mechanisms to anti-HER2 therapies in HER2positive breast cancer: current knowledge, new research directions and therapeutic perspectives. Critical reviews in oncology/hematology. 2019. doi: 10.1016/j.critrevonc.2019.05.001.

102. Li Y, Zhang T, Pang Y, Li L, Chen Z-N, Sun W. 3D bioprinting of hepatoma cells and application with microfluidics for pharmacodynamic test of Metuzumab. Biofabrication. 2019;11(3):034102. doi: 10.1088/1758-5090/ab256c.

103. Maximiano S, Magalhaes P, Guerreiro MP, Morgado M. Trastuzumab in the treatment of 
breast cancer. BioDrugs. 2016;30(2):75-86. doi: 10.1007/s40259-016-0162-9.

104. Tolba MF, Omar HA. Immunotherapy, an evolving approach for the management of triple negative breast cancer: Converting nonresponders to responders. Critical reviews in oncology/hematology. 2018;122:202-7. doi: 10.1016/j.critrevonc.2018.01.005.

105. Iwata TN, Ishii C, Ishida S, Ogitani Y, Wada T, Agatsuma T. A HER2-targeting antibodydrug conjugate, Trastuzumab Deruxtecan (DS-8201a), enhances antitumor immunity in a mouse model. Molecular cancer therapeutics. 2018;17(7):1494-503. doi: $10.1158 / 1535-7163$.
106. San-Juan-Rodriguez A, Parekh N, Newman TV, Hernandez I. Pricing of monoclonal antibodies in the United States. Global Journal on Quality and Safety in Healthcare. 2018;1(1):4-5. doi: 10.4103/JQSH.JQSH_1_18.

107. Hay AE, Cheung MC. CAR T-cells: costs, comparisons, and commentary. Taylor \& Francis; 2019. doi: 10.1080/13696998.2019.1582059. 